\title{
The sinking ship policy to the perpetrator of illegal, unregulated and unreported fishing in criminal law perspective
}

\author{
Agus Raharjo*, Tedi Sudrajat ${ }^{2}$, Rahadi Wasi Bintoro ${ }^{3}$, and Yusuf Saefudin ${ }^{4}$ \\ ${ }^{1}$ Department of Criminal Law, Faculty of Law, Jenderal Soedirman University, Purwokerto - \\ Indonesia \\ ${ }^{2}$ Department of Administrative Law, Faculty of Law, Jenderal Soedirman University, Purwokerto - \\ Indonesia \\ ${ }^{3}$ Department of Procedure Law, Faculty of Law, Jenderal Soedirman University, Purwokerto - \\ Indonesia \\ ${ }^{4}$ Indonesian Teachers' Association of Victimization J1. Prof. dr. HR Boenyaim 708 Purwokerto - \\ Indonesia
}

\begin{abstract}
The sinking ship policy by Minister Susi Pudjiastuti to the perpetrator of illegal, unregulated and unreported (IUU) fishing in the territorial sea of Indonesia raises the pros and cons from many perspectives. The policy background and policy legal consequences in criminal law perspective are the problems that will be discussed in this article. The research method is normative and empirical research. The results showed that the policy comes since the previous Government let perpetrators of the theft of fish in the sea of Indonesia. This caused losses for Governments as well as the fishermen who technically cannot compete in terms of fishing technology. The sinking ship policy also made due to the slowness of criminal justice cases against illegal, unregulated and unreported fishing in Indonesia which obviously does not comply with the principle of quick, simple and low cost justice. However, this policy is problematic in criminal law perspective, especially against the application of presumption of innocence principle and the proof process in criminal justice. Therefore, there needs to be laws that can be used as a guide and protector for this policy. Thus there is no problem in the future and instead become a breakthrough in fisheries law enforcement..
\end{abstract}

\section{Introduction}

There is a paradox that can be found in this country. On the one hand, we should be proud because Indonesia is one of the mega-biodiversity countries [1], where some of its territories are included in the biodiversity hotspots of Sundaland (West Nusantara) and Wallacea [1, 2], others still have natural ecosystems with high biodiversity of Sahulland (East Nusantara), and become the center of the world's coral triangle $[3,4,5,6]$.

\footnotetext{
${ }^{1}$ Corresponding author: agus.raharjo007@gmail.com
} 
However, on the other hand, we should be saddened by the existing conditions, in which Indonesia became one of the countries with the highest extinction rate of biodiversity in the world. Natural habitat conversion is a major cause of biodiversity loss - illegal deforestation and conversion to oil palm plantations, whereas in the ocean biodiversity is lost due to the uncontrolled IUU Fishing [7] and a major threat to the sustainability of marine food resources [8].

Indonesia as an archipelagic country has approximately 5.8 million $\mathrm{km}^{2}$ of marine sea ( $75 \%$ of the total area of Indonesia), consisting of 0.3 million $\mathrm{km}^{2}$ territorial sea sea, 2.8 million $\mathrm{km}^{2}$ of marine sea of the archipelago, and 2.7 million $\mathrm{km}^{2}$ Exclusive Economic Zone of Indonesia (ZEEI). Based on data from the Geospatial Information Agency (BIG), Indonesia's coastline reaches $99,093 \mathrm{~km}$ [9]. The potential of fish resources in the area is estimated at 6.4 million tons per year [10], should be the driving force for economic development and welfare of the community, especially fishermen. However, the life of fishermen in Indonesia identic with poverty [11].

The limitation of fishing gear and vessel are technical reasons which are not the only one reason, but the illegal fishing activities of foreign and domestic fishermen that cause great potential were not explored to the maximum potential. Illegal fishing poses a threat to global food security [12], as the contribution of this activity reaches $30 \%$ of the total world catch $[13,14]$. Indonesia's economic losses due to illegal fishing according to FAO reach Rp 30 trillion per year [15], but the loss number shown by the Ministry of Marine Affairs and Fisheries is even more fantastic, that is 20 million US dollars every year. This is only economic loss mentioned, not to mention losses due to marine ecosystems damage that could affect the sustainability of potential fishing in Indonesia [16].

Based on the background of unexplored potentials, unbridle illegal fishing, and especially changes in government policy since 2014, which emphasizes the vision of Indonesia as a maritime country, so the steps towards improvements in law enforcement are conducted. One of the most controversial policies is the ship sinking caught doing illegal fishing in the ocean of Indonesia. Actually, this policy is not a new thing, because it is regulated in Article 69 Verse (4) of Law no. 45 of 2009, stated that in carrying out its functions, the fishery investigator and/or supervisor may take special action in the form of burning and/or drowning of a foreign-flagged fishing ship on the basis of sufficient preliminary evidence.

In the period of 2009-2012 the number of ship that were excoriated only 37 ships were drowned [17]. However, since 2014-2016, the government has drowned 151 ships $(18,16]$.

This policy caused controversy, both on a practical and theoretical level. On a practical level, this policy is widely criticized by neighbour countries and foreign fishermen who have reduced their fish catch, as well as by domestic fishermen who do not comply with the rules of fishing in Indonesia's teritory. At the theoretical level, the sinking of ships without the judicial process does invite problems, let alone the vessel can serve as evidence in the trial. Based on Article 46 Verse (2) of the Criminal Procedure Code, evidence can be returned to the rightful, deprived of the state, or seized for destruction, or seized for evidence of another matter. This can be done if the trial is completed. These issues will be discussed in this paper as the hope of clarifying the legal position of the illegal fishing ship drowning in Indonesian criminal law.

\section{Research Methods}

The approach method used to answer the problem is the normative and empirical approach. In the normative approach, the law is seen as building a system of norms/rules that should support each other and not against in a system. The empirical approach is used to assess the facts, both in the form of factors causing law enforcement in the field of 
fisheries, the value of losses due to illegal fishing and policy implementation. Research data form is in the primary, secondary and tertiary legal material obtained through literature study which analyzed with qualitative analysis.

\section{Causative Factors and Value Losses Due to IUU Fishing}

In general, the vastness of Indonesian sea and the richness embodied in the sea is an attractiveness for anyone to use them, not least for criminals. Illegal fishing is a generic term for calling them, but as the time running, this term is not limited to "thieves" alone, extends to those who do not report the catch or fish in places that are prohibited by the authorities. Understanding Illegal, Unreported and Unregulated Fishing based on International Plan of Action (IPOA) which was initiated by FAO, script on IUU Fishing, are as follows $[19,20]$ :

(1) Illegal fishing is an illegal fishing activity which:

a. Conducted by national ships or foreign ships in sea under the jurisdiction of 1 (one) country, without the consent of that country, or contrary to its laws and regulations;

b. Conducted by ships flying the flag of a member country of a regional fisheries management organization but acting contrary to the conservation and management provisions established by that regional organization and binding the country, or other relevant international law provisions, or;

c. Violate the provisions of national law or other international obligations, including those committed by states in cooperation with a related regional fisheries management organization

(2) Unreported fishing is a fishing activity that:

a. Not reported, or deliberately reported by giving incorrect data to the authorities of the relevant national authorities, which are contrary to applicable laws or regulations in that country, or;

b. Conducted within the territory competence of a regional fisheries management organization, where such activity is not reported or misreported, thus contrary to the reporting procedures of the organization.

(3) Unregulated fishing is a fishing activity carried out:

a. In territories under the management of a regional fisheries management organization, by ship without nationality, or by ship flying the flag of a nonmember country of the organization, or by a fishing entity, in a manner which is neither appropriate nor contrary to the provisions conservation and management measures of the organization, or;

b. In the territory or on fish stocks that have no management and conservation arrangements, where such activities are carried out in a manner contrary to state responsibility under international law on marine biological resource conservation.

The extent of IUU Fishing can actually be a safety net for Indonesia to secure and utilize its marine wealth. Current government policies that pay more attention to the development of maritime axis is also a driver for law enforcement in Indonesian sea. There are 3 (three) Fisheries Management Areas (FMA) that are often victims of illegal fishing practices: FMA of South China Sea, there is decrease in stock density and demersal fish species size; Arafura Sea FMA there is a decrease in stock and weight of shrimp; and FMA of the Indian Ocean, a decrease in the number of catch and weight of tuna [21]. IUU Fishing is a factor that causes Indonesia can not maximally utilize its marine wealth. The rise of IUU Fishing is caused by many factors that influence it.

There are 7 factors causing illegal fishing in Indonesia, namely: (1) world fish demand is increasing, while world supply is decreasing, overdemand occurs especially for certain marine fish such as tuna, it is imendorong fishery world hunting fish anywhere by legal or 
illegal; (2) the price disparity of fresh fish intact in other countries than in Indonesia is quite high; (3) fishing ground in other countries is already exhausted, while in Indonesia is still promising, whereas they must maintain the fish supply for their consumption and must maintain the production of processing in the country; (4) the Indonesian sea is very wide and open, on the other hand supervision capability is still very limited; (5) fish processing system in the form of licensing system is open, the limitation is only limited to fishing gear, so it is less suitable if faced with factual condition of Indonesia geography, especially ZEE Indonesia bordered with another countries' sea; (6) the limited number of monitoring facilities and infrastructure and human resources supervision; and (7) the perception and cooperation of law enforcement apparatus in handling of criminal case of fishery still not solid, especially in terms of understanding legal action and commitment of supervising ship operation in ZEE [8, 7]

Due to the rampant illegal fishing, caused not only losses in terms of economy but also in terms of ecology. Supervision and Control of Marine and Fishery Resources (Pengawasan dan Pengendalian Sumber Daya Kelautan dan Perikanan/P2SDKP) discloses, some of the economic losses due to IUU fishing are (1) fishery levies paid by the tariff of Indonesian ship; (2) fuel subsidies enjoyed by unauthorized foreign ships; and (3) stolen fish production (volume and value). This loss is the impact of illegal fishing because of the direct loss of catch value that should be accepted by every coastal state [22, 21, 23, 24].

If an example is taken from one part of the Indonesian sea, Arafura Sea, it appears that the losses due to illegal fishing in the sea reached US \$ 4 billion. When it calculated losses due to illegal fishing in the sea Arafura since 2001 - 2013, then the value can reach a fantastic amount, which is 0.52 Quadrillion rupiah (520 trillion rupiah, assuming exchange rate $\$ 1=\mathrm{Rp} \mathrm{10,000)} \mathrm{[8].} \mathrm{Economic} \mathrm{losses} \mathrm{can} \mathrm{be} \mathrm{calculated} \mathrm{mathematically,} \mathrm{but} \mathrm{there} \mathrm{are}$ other disadvantages that are more important and can not be judged materially but are strongly related to the nation's self-esteem is the destruction of the image of Indonesia in the international because it is considered as unmanageable fisheries [25].

There are other problems in the management of marine resources, they are: (1) the use of net that violates the rules; (2) illegal transport of cargo in the middle of the sea, since the volume of cargo is not recorded at the port and as a result is not taxed; (3) the hunting of protected marine animals, where Indonesia is the world's largest shark kill, although this is against the rule. A total of 73 million sharks are killed every year just for the fins only. Hundreds of thousands of tons of sharks are captured by 7 countries alone. The main shark finers are Hongkong and China [26]. Despite protection laws and marine conservation areas, more efforts are needed to stop the slaughter of sharks [7]. Based on studies from UCSB and Research and Development Center Marine and Fisheries, if exploitation continues, fish biomass in Indonesian sea will drop to $80 \%$ by 2035 [27].

These issues are what the government wants to solve, one of them is the issuance of the ship's sinking policy. The value of large losses due to illegal fishing, the impact that is generated for both the state economy and the decline in the welfare of fishermen become a consideration of this controversial policy. The hope for sovereignty in the sea of the archipelago and the development of maritime axis which is the government's policy today is a strategic step to realize the welfare of the people, especially fishermen.

\section{Criminal Law Perspective on Sinking IUU Fishing Shipper}

There are 4 (four) aspects of the study related to the criminal law, namely the actions (criminal acts), people who commit crimes, punishment, and victims of crime. When referring to Law no. 45 of 2009 on Amendment to Law no. 31 of 2004 on Fisheries, these four aspects already exist in the arrangement, namely: the first aspect of the forbidden act is 
in Article 84 - Article 105; the subject of criminal offenses in the form of persons and corporations, although in corporate matters still contain controversy regarding the noncriminalization of corporations when committing a fishery crime (Article 101); the main types of punishment are two, namely prison within a certain time and a fine; and about the victims, of course the country and people of Indonesia (especially fishermen).

When referring to some research results, there are various ways of foreign fishing ship to conduct illegal fishing activities in the Arafura Sea, among them by falsifying permits and numbers on the hull of their ship, doing illegal fishing techniques in Indonesia, using Indonesian flags, arresting the night are, using some crew members of Indonesian citizenship, and so forth. Of the various types of illegal fishing by foreign fishing ship in the Arafura Sea, at most is to use the way of falsifying permits and writing the number of fake ships on board. This method is mostly found in the Arafura Sea, in addition to stealing fish, this ship can benefit refueling fuel (at government subsidized prices) and other supplies at the Fishery Port of Indonesia [8]. Such modus operandi is covered by article 84 until article 105.

Sinking vessel policy is actually stated in Article 69 verse (4) of Law no. 45 Year 2009, but the implementation until 2015 is not effective. The previous Government let perpetrators of the theft of fish in the sea of Indonesia. This caused losses for Governments as well as the fishermen who technically cannot compete in terms of fishing technology. The sinking ship policy also made due to the slowness of criminal justice cases against illegal, unregulated and unreported fishing in Indonesia which obviously does not comply with the principle of quick, simple and low cost justice. Therefore, the new government then set up a Task Force on Eradication of Illegal Fishing (Satgas 115) approved by President Joko Widodo through Presidential Decree no. 115 T 2015. Task Force 115 is a one roof enforcement system consisting of elements of the Navy, Police, Marine Security Agency (Badan Keamanan Laut/BAKAMLA) and the Attorney General, facilitating coordination, encouraging synergies, and implementing facilitation functions in combating illegal fishing [27].

The fishery law is a special law or special criminal law, which has a specificity compared to the general criminal law concerning the conduct, arrangement, legal subject, punishment, or judicial and procedural law. Based on such matters, then, pursuant to the perspective of criminal law, the sinking of ships or any action existing or regulated in such special legislation is allowed and valid, even against the common criminal law (material or formal). The problem that arises is the act of sinking the ship as it is legitimate so it is not considered a vigilante action.

When referring to Article 69 verse (4), the act of sinking the vessel may be carried out by the investigator on the basis of "sufficient initial evidence". When referring to a general definition in the criminal procedural law concerning such words, Article 17 of the Criminal Procedure Code provides that an arrest warrant is made against a person alleged to have committed a crime on the basis of sufficient evidence of the matter. The explanation of this article confirms that a sufficient initial proof is a proof of the beginning to suspect a criminal offense.

The development of the meaning of the word came after the decision of the Constitutional Court No. 21/PUU-XII/2014 declare unconstitutional conditional on the phrase "preliminary evidence", "sufficient preliminary evidence", and "sufficient evidence" in Article 1 number 14, Article 17 and Article 21 verse (1) Criminal Procedure Code, evidence in accordance with Article 184 Criminal Prosedure Code (witness testimony, expert statement, letter, guidance, and description of defendant). The Constitutional Court 
considers the minimum requirement of two evidence and examination of the candidate for the transparency and protection of a person's rights so that before a person is designated as a suspect he has been able to give a balanced account. This avoids any arbitrary action by the investigator, especially in determining sufficient preliminary evidence.

What is described in the Criminal Prosedure and the decisions of the Constitutional Court is related to the determination of status or action on the subject of law (human) in the investigation, but what is required as "sufficient initial evidence" in Article 69 verse (4) of Law no. 45 Year 2009 is on the object or tool used for crime (ship) which incidentally is not a legal subject. This can be seen from the explanation of the article, that is, "sufficient initial evidence" is the preliminary evidence to suspect a criminal offense in the field of fisheries by foreign-flagged fishing ship, for example, foreign-flagged fishing boats do not have Fishing Permit (Surat Ijin Penangkapan Ikan/SIPI) and Fishing Vessel License (Surat Ijin Kapal Pengangkut Ikan/SIKPI), as well as apparent fishing and/or transporting fish when entering the fishery management area of the Republic of Indonesia. The word in italics indicates that the perpetrator of a fishery crime is a ship, not a human being. The new thing, in this case, is to establish the status of the object or tool of crime (to be drowned, seized, or seized by the state) used the standard to establish the status of the legal subject in the criminal procedure law; and the establishment of a new legal subject, ie objects (ships) as criminals. Can these judgments be judged equally by establishing equal positions between humans and things?

It seems that lawmakers use the precautionary principle when using the requirements for the determination of legal subject status (human and corporate) on the determination of action against ship used for illegal fishing. At this point, the argument is acceptable, but the ship is not a mere human object, then a fishery law is directed to an object or a human being. Ships are only tools, which, when used for crime, fall into the category of evidence. Under Article 76A, this evidence may be destroyed, auctioned or handed over to a group of fishermen or cooperatives for use. At this point, the principle of the benefit of evidence in the ship's sinking policy is not achieved. Destruction of evidence can only be done if the goods are really dangerous if used by the public, such as narcotics, psychotropics, liquor, and others after obtaining approval from the local district court chairman. The question is what is the danger of a ship if it has been seized or taken away by the state?

At the practical level, policy brings significant change. Recorded until October 2017 has been drowned 317 ships and 90 other ships waiting for execution. Minister Susi Pudjiastuti claims this policy raises fish stocks by nearly 10 million tons per year (2015) to 12.54 million tons per year (2016). National fish consumption rose to $7 \mathrm{kp} / \mathrm{capita}$. As a result, the exchange rate of fishermen also increased because the fish in the local market is easily accessible and the price is not too expensive [28].

In the making policies should be based on strong theoretical studies and followed by accurate implementation. Criminal law in the field of fisheries is included in a special criminal law that may create rules that deviate or conflict with the general criminal law. However, such deviations should be followed by strong arguments, including if they are related to the basic principles of criminal law. This explanation is important in criminal law in order to be a material for the development of theory, and in practical terms, it can be translated correctly so that there is no gap between theory and practice. 


\section{IUU Fishing Prevention and Countermeasures}

The prevention and control of IUU Fishing is not an easy thing, considering the position of Indonesian sea bordered on 10 countries so that cooperation between countries becomes an important issue. However, bilateral and regional cooperation has not been able to overcome the problem of illegal fishing in Indonesian sea [29]. It still takes more than a political step to realizing sovereignty in Indonesian sea.

Some policies that have been issued to achieve this are the moratorium on the issuance of licenses for foreign fishing ship for six months; Ministry of Marine Affairs and Fisheries Regulation no. 57 of 2014 which prohibits transshipment or sale of fish in the middle of the sea [30]; there is also Presidential Regulation no. 44 of 2016 on a negative list of foreign investments stating that fishing is closed to foreigners [27]; and some bilateral and regional cooperation with some neighboring countries.

There are several examples of research that can be taken into account by preventing and tackling IUU Fishing, such as charting. The baganisasi policy in addition to empowering existing fishermen is expected to reduce the activity of border water territorial violations by fishing ship from other countries. Thus the charting program will not only improve the economy of the border community but also be able to overcome the border problems of the region with neighboring countries [31]. The results of Solihin et.al [20] show that there are problems in eradicating illegal fishing in Sebatik Island, Kab, Nunukan, East Kalimantan due to low sea patrols and weak coordination of law enforcement apparatus. The charting policy has a positive impact, because: (a) impedes the entry of foreign fishermen; (b) shows the control of sea by RI, and (c) Other State Naval Ships entering the territorial sea of Sebatik Island and its surroundings.

Some international provisions can also be adopted to realize water sovereignty from the threat of illegal fishing. According to rule 19 in Safety of Life at Sea (SOLAS) V in 2002, the International Matrition Organization (IMP) determined that any ship weighing more than 300 GT (Gross tonnage) are required to have their Automatic Identification System (AIS) transmitters. This rule requires each of the ship to continue communicating AIS signals unless they are in a location where there are regulations prohibiting communication on such information [32].

International regulations require every ship above 300 GT to send a data using AIS to be an opportunity to detect ships doing fish theft. Indonesia's ability to detect AIS signals from LAPAN-A2 / Orari satellites enlarges the opportunity. The detection process is done by analyzing the travel data from the AIS system. The types of fish thefts that can be detected by this algorithm are trans-shipment, tiger trawls, territorial zone violations, nonreporting violations, violation of capture areas, and violations do not activate the AIS transmitter [33].

The prevention and handling of illegal fishing are not enough only by the issuance of policies, the application of research results or the adoption of international arrangements on fishing rules, the use of fishing gear or the utilization of technology. Prevention and mitigation of illegal fishing is the joint responsibility of all elements of the nation. There needs to be the involvement of the most relevant parties, the fishermen as the front guard in sea supervision where they rely on and depend on marine resources. Therefore, it is necessary to raise awareness about the important role of fishermen in safeguarding Indonesian sea through skills education and training not only in fishing capability but also in maintaining the sovereignty of fisheries in the Indonesian sea.

The empowerment of local wisdom in the prevention of illegal fishing is also worth considering because it is proven to be implemented in several areas [34, 35]. More than that is to prevent abuse of power from the law enforcement apparatus or the so-called "unscrupulous", in order not to use its power and authority to seek its own advantage. 


\section{Conclusion}

Natural wealth contained in the Indonesian ocean is an attraction for anyone who wants to use it. Illegal fishing is a way of exploiting marine wealth that is not legally and ecologically destructive. The ship's sinking policy is an attempt to prevent and cope with illegal fishing which has caused much controversy. Practically this policy brings the benefits of decreasing the number of illegal fishing in Indonesian sea, increasing the number of fisheries production and fishermen welfare. On the other hand, this policy from the side of the criminal law contains issues particularly related to the phrase "sufficient initial evidence" as a condition of vessel sinking, the determination of the vessel as a legal subject (the perpetrator of the crime), and the actual value of the vessel's benefit is more useful than drowned. Criminal law in the field of the fishery is a special criminal law that may deviate from the general criminal law, but the deviation should be followed by a complete and accurate explanation in order to avoid debate and misinterpretation.

The researcher would like to express gratitude to some of the parties who has helped researcher during looking for data and finishing this paper. First and foremost, the researcher express thank you to Chairman of research institutes and community service, Dean of Faculty of Law, Jenderal Soedirman University. Also, thanks for my student, Luthfi Kalbuadi and Imas Puji Nuryanti, which has been helpful in searching data. Hopefully the help given will receive a reply from Allah SWT.

\section{Reference}

1. R.A. Mittermeier, P.R Gil, M. J. Pilgrim, T. Brooks, C.G. Mittermeier, J. Maloreux, G.A.B. da Fonseca, P.A. Seligmann, and H. Ford. Hotspots Revisited: Earth's Biologically Richest and Most Endangered Terrestrial Ecoregions. (Conservation International, New York, 2005)

2. L.J. Gorenflo, S. Romaine, R.A. Mittermeier, K. Walker-Painemilla. Proc Natl Acad Sci USA 109, 8032-8037 (2012)

3. J.E.N. Veron. Coral of the World. (3 Volumes). (Australian Institute of Marine Science. Townsville, Queensland, 2000)

4. C. M. Roberts, C.J. McClean, J.E.N. Veron, J.P. Hawkins. G.R Allen, D.E. McAllister, C.G. Mittermeier, F.W. Schueler, M. Spalding, F. Wells, C.T.B. Werner. Science. 292, 1280-1284 (2002)

5. TNC. Coral triangle facts, figures and calculations: Part II: Patterns of Biodiversity and Endemism. (The Nature Conservancy, Arlington VA, 2008)

6. UNEP-WCMC, WorldFish Center, WRI, TNC. 2010. Global distribution of warmwater coral reef, compiled from multiple sources including the Millennium Coral Reef Maping Project.

7. Sutarno, A. D. Setyawan. Prosiding Seminar Nasional Masyarakat Biodiversity Indonesia, 1, 1-13 (2015)

8. P. Rahardjo. Pandangan Ilmiah pada Workshop on Parameters and Indicators of Habitats to be Expressed in Map of Trawl Fishing Gear Management in Arafura Sea, Kerjasama Ditjen Perikanan Tangkap dengan Food Agriculture Organization (FAO), Royal Hotel Bogor, 1-18 (2013)

9. G. Samantham. National Geographic, 21( 2013) 
10. R. Dahuri. Cetak Biru Pembangunan Kelautan dan Perikanan Menuju Indonesia Yang Maju, Adil-Makmur, dan Berdaulat. (PKSPL-IPB, Bogor. 2010)

11. E. Sutrisno. Jurnal Dinamika Hukum. 14, 1-12 (2014)

12. Agnew. Estimating the Worldwide Extent of Illegal Fishing. J. Plosone. 4, 1 1-8 (2009)

13. A. Solihin. J. Mar. Fisheries, 1, 113-210 (2010)

14. A. Solihin. Politik Hukum Kelautan dan Perikanan. (Bandung, Penerbit Nuansa Aulia, 2010)

15. P2SDKP. Refleksi 2007 dan Outlook 2008: Pengawasan dan Pengendalian Sumberdaya Kelutan dan Perikanan. (Jakarta, PSDKP, 2008)

16. M. R. Isnurhadi. Sekuritisasi Illegal. J. Hub. Int. 10, 13-27 (2017)

17. DetikFinance. RI sudah Tenggelamkan 38 Kapal Asing Illegal. (, 2016)

18. D.H. Agung. Susi telah Tenggelamkan 151 Kapal Pencuri Ikan. Tirto.id, http://tirto.id/susi-tenggelamkan-151-kapal-pencuri-ikan-ED, accessed Maret 21, 2018.

19. A. Gustina. J. Dinamika Hukum. 14, 340-349 (2014)

20. A. Solihin, S. Koeshendrajana, and F. Y. Arthatiani. Paper on Seminar Nasional Tahunan IX Hasil Penelitian Perikanan dan Kelautan, (Yogyakarta, 1-18, 2012)

21. A. Solihin, M. Imron, dan A. Wahyono. Buletin PSP. 20, 205-211 (2012)

22. Marine Resource Assessment Group Ltd (MRAG). Review of Impact of Illegal, Unreported and Unregulated Fishng on Developing Countries. Final Report.( London, MRAG)

23. R. Yulianti and M. Ikhwan. J. Dinamika Hukum 18, 29-36 (2018)

24. E. Sutrisno, and R. Apriani. J. Dinamika Hukum 17, 266-272 (2017)

25. G.A. Wagey, S. Nurhakim, V.P.H. Nikijuluw, Badrudin, T.J Pitcher. A Study of Illegal, Unreported and Unregulated (IUU) Fishing in the Arafura Sea, Indonesia. (Research Center for Capture Fisheries, Agency of Marine and Fisheries Research, Jakarta, 2009)

26. Save Our Seas. How many sharks are caught each year? Save Our Seas Foundation. 2013.http://saveourseas. com/articles/how_many_sharks_are_caught_each_year, access on January 15, 2015.

27. Marta, and M. Fajar. Susi dan Tiga Pilar yang Tak Sekadar Mitos. Kompas. September 07, 2017. Accessed Oktober 10, 2017. http://ekonomi.kompas.com/read/2017/09/07/ 051546726/susi-dan-tiga-pilar-yangtak-sekadar-mitos.

28. Haruskah Susi Pudjiastuti Berhenti Menenggelamkan Kapal? http://www.dw.com/id/ haruskah-susi-pudjiastuti-berhenti-menenggelamkan-kapal/a-42077235.

29. S. V. Muhammad. Politica 3, 59-85 (2012)

30. P. A. N. Indra. Tenggelamkan Kapal Lagi, Bu Susi? Tirto.id, Agustus 04, 2016. http//tirto.id/ tenggelamkan-kapal-lagi-bu-susi-bw5E, accessed Maret 21, 2018

31. Koesrianti. J. Mimbar Hukum 20, 193-410 (2008)

32. IMO. SOLAS 1974: Brief History - List of amendments to date and where to find them. (2013) http:/www.imo.org/ en/ KnowledgeCentre/ Reference AndArchives/ HisoryofSOLAS/Documents. Access date June 20, 2017. 
33. E.M. Husni, M. Riksa, R.S. Andanawari, and R. H. Triharjanto. Jurnal Teknologi Dirgantara. 14, 81-90 (2016)

34. J. M. Monteiro. J. Dinamika Hukum. 17, 83-88 (2017)

35. Adwani, Mahfud, and Rosmawati. Jurnal Dinamika Hukum 16, 1-7 (2016) 